Naohiko Seki • Masa-aki Muramatsu • Sumio Sugano

Yutaka Suzuki · Akira Nakagawara • Miki Ohhira

Akiko Hayashi • Tada-aki Hori • Toshiyuki Saito

\title{
Cloning, expression analysis, and chromosomal localization of HIP1R, an isolog of huntingtin interacting protein (HIP1)
}

Received: May 18, 1998 / Accepted July 13, 1998

\begin{abstract}
Huntington disease (HD) is an inherited neurodegenerative disorder which is associated with CAG expansion in the coding region of the gene for huntingtin protein. Recently, a huntingtin interacting protein, HIP1, was isolated by the yeast two-hybrid system. Here we report the isolation of a cDNA clone for HIPIR (huntingtin interacting protein-1 related), which encodes a predicted protein product sharing a striking homology with HIP1. RT-PCR analysis showed that the messenger RNA was ubiquitously expressed in various human tissues. Based on PCR-assisted analysis of a radiation hybrid panel and fluorescence in situ hybridization, HIP1R was localized to the q24 region of chromosome 12.
\end{abstract}

Key words Huntingtin interacting protein (HIP1) $\cdot$ Leucine zipper - Chromosome 12q24 · Full-length enriched cDNA library $\cdot$ Neuroblastoma

\section{Introduction}

Huntington disease (HD) is inherited as an autosomal dominant disease that gives rise to progressive, selective neural cell death associated with choreic movements and dementia (Harper 1991). The disease is associated with increases in the CAG triplet repeat length present in a gene

N. Seki, A. Hayashi, T. Hori, and T. Saito $(\varangle)$

Genome Research Group, National Institute of Radiological Sciences, 4-9-1 Anagawa, Inage-ku, Chiba 263-8555, Japan

Tel. 81-43-206-3135, Fax 81-43-251-9818, e-mail:t_saito.nirs.go.jp.

M. Muramatsu

Helix Research Institute, Kisarazu, Chiba 292-0812, Japan, and Department of Bioregulation, Medical Research Institute, Tokyo Medical Dental University, Tokyo, Japan

S. Sugano, Y. Suzuki

Department of Virology, Institute of Medical Science, The University of Tokyo, Tokyo, Japan

A. Nakagawara, M. Ohira

Division of Biochemistry, Chiba Cancer Center, Chiba, Japan called huntingtin located on chromosome 4p16.3 (Ross et al. 1995; Zoghbi et al. 1996). In HD, CAG expansion beyond 35 repeats usually results in a clinical phenotype (HDCRG 1993; Kremer et al. 1994). There is a strong inverse relationship between CAG size and age of onset of this disease (Andrew et al. 1993; Duyao et al. 1993; Snell et al. 1993). Wanker et al. (1997) hypothesized that binding proteins, with a restricted pattern of expression, specific to the elongated polyglutamine stretch of the huntingtin protein, could cause selective vulnerability in particular cells. At present, three huntingtin interacting proteins have been identified, such as huntingtin-associated protein ( $\mathrm{Li}$ et al. 1995), the glycolytic enzyme GAPDH (Burke et al. 1996), and the ubiquitin-conjugating enzyme hE2-25K, also named HIP2 (Kalchman et al. 1996). Recently, another huntingtin interacting protein, HIP1, was isolated by yeast two-hybrid screening. HIP1 shares homology with Sla2p, a component of cytoskeleton in Saccharomyces cerevisiae (Kalchman et al. 1997; Wanker et al. 1997).

In the present study, cDNA for a HIP1-related protein (HIP1R) was cloned from a full-length enriched cDNA library constructed from a neuroblastoma sample using the oligo-capping method as described previously (Maruyama and Sugano 1994; Suzuki et al. 1997). Here we report the sequence feature, expression profile, and chromosomal assignment of the HIP1R gene.

\section{Results and discussion}

The HIP1R cDNA clone was revealed from a one-pass sequence to be the most homologous to HIP1 (accession number U79734). The entire sequence of this clone was determined by a shot-gun strategy (Seki et al. 1997). The isolated HIPIR cDNA clone was $3876 \mathrm{bp}$ in length and had a single ORF of 890 amino acids. The predicted protein had a calculated molecular weight of approximately $99 \mathrm{kDa}$. The nucleotide sequence data reported here will appear in the DDBJ, EMBL, and GenBank nucleotide sequence databases with the accession number of AB013384. A canonical 
humH I P 1

humH I P 1 R

S1a 2 p

humH I P 1

humH I P 1 R

Sla $2 p$

humH I P 1

humHIP 1 R

Sla $2 p$

humH I P 1

humHIP I R

Sla 2 p

humH I P 1

humH I P 1 R

Sla $2 p$

humH I P 1

humH I P 1 R

Sla $2 p$

humH I P 1

humHIP1R

Sla 2 p

humH I P 1

humH I P 1 R

Sla 2 p

humH I P 1

humH I P 1 R

Sla 2 p

humH I P 1

hUMHIP 1 R

Sla 2 p

humHIP 1

humHIPIR

Sla $2 p$

hu mH I P 1

humHIP1R

Sla 2 p

h u mH I P 1

humH I P 1 R

S 1 a $2 p$

humH I P 1

humH I P 1 R

Sla $2 \mathrm{p}$

hu mH I P 1

humHIPIR

Sla $2 p$

hu mH I P 1

humH I P I R

Sla 2 p

hu mH I P 1

humHIPIR

S1a 2 p

humH I P 1

humH I P $1 \mathrm{R}$

Sla $2 \mathrm{p}$

humH I P 1

humHIPIR

Sla $2 p$

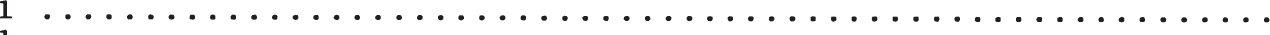

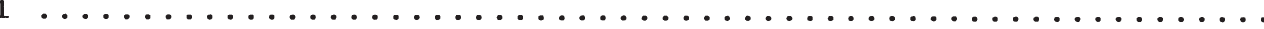

1 MSRIDSDLQKALKKACSVEETAPKRKHVRACIVYTWDHQSSKAVFTTLKTLPLANDEVQL

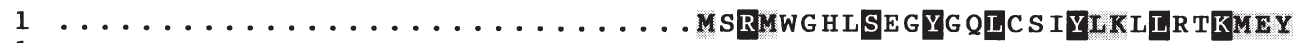

1 (1)

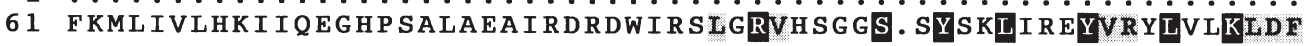

HTKN PRFPGNLQMSDRQLDEAG ESDVNN F FQLTVEMF D YLEC E LNLFOTVFNS LDMSRSV

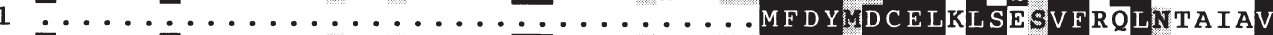

120 HAHHRGFNNGTFEYEEYVSLVSVSDP DEGYETILDLMSLQDSLDEFSOIIFASIO . . . . .

90 SVTAAGQCRLAPL I QV ILDCSHLYDYTVKLLFKLHSCL . . . . PADTLQGHRDRFMEQFTK

26 SQMSSGQCRLAPLI QV IQDC SHLYHYTVKLLFKLHSCL. . . . PADTLQGHRDRFHEQFHS

175 SERRNTECKI SAL I PLIAESYG IYKF I T SMLRAMHRQLNDAEG DAALQP LKERYELQHAR

146 LKDLFYRSSNLQYFKRL I I PQL P ENP PNF LRASALSEH ISPVVV I PAEASS PDSE PVLE

82 LRNFFRRASDMLYFKRLIQI PRLPEGP PNFLRASALAEH I K PVVVI PEEAPE. DEE PENL

235 LFEFYADCSSVKYLTTLVTI PKL PVDAPDVFLINDVDE. SKEIKFKKREPSVTPARTPAR

206 KDDLMDMDAS QQNLF DN KF DD IF GS S F S S D P F N N S QNGVNKDEKDHLIERLYREISGLK

141 IEISTGPPAGE PVVVADLF DQTFGPP.......... NGSVKDDRDLQI ESLKR EVEMLR

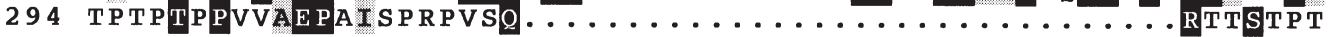

266 AQLENMKTES . . QRVVLQLKGHVSEL . . . . EADLAEQQHLRQQAADDCEFLRAELDELRR 190 SELEKIKLEA. . QRYIAQLKSQVNAL. . . . EGELEEQRKQKQKALVDNEQLRHELAOLRA 322 GYLQTMPTGATTGMMIPTATGAANAIF PQATAQMO P FWANQQAQFANEONR. .LEQERV

320 QRE D TEKA QR SLSEIER KAQANEQRYSK L K E KYS E LVQNHA D L L R K N AEVTK OV SMARQA 244 AQLEGERSQGLREEAERKASATEARYNKLKEKHS L VHVHAELLRKNADTAK QLTVTQQS 380 Q $L Q Q Q Q A Q Q E L F Q Q Q L Q K A Q Q D M M N M Q L Q Q Q N \cdots . . Q$ QHQNDLIALTNQYEKDQALLQQY

380 QVDLEREKKELEDSLER I S QGQRKTQEQLEVLESLKQELATSQRELQVLQG SLETSAOS 304 QE EVARVKEQLAF QVEQVKRES L LKLEEKS DO LEKLKRELEAKAGE LARAOEALSHTEQS 436 DQRV. . . QQLESEITTMDSTASKQLANKDEQLTALQDQLDVWERKYESLAKLYSQLRQE

440 EANWAAEFAELEKERDSLVSGAAHREE . ELSALRKELQDTQLKLA . . . . . . . . . . . . . 364 KS ELS SRLDTLSAEKDALSGAVRQREA. DLLAAOSLVRETEAALSREQQRS SQEQG ELQG 492 HLNLLPRFKKLQLKVNSAQESIQKKEQLEHKLKQKDLQMAE LVKDRDRARLELERS . INN

484 ..... STEE SMCQLAKDQRKMLLVGSRKAAE QVI QDALNQLEEPP L ISCA . GSADHLLS 423 RLAERESQEQGLRQRLLDEQFAVLRGAAAEAAGIIQDAVSKLDDP LHLRCT . SS P DYVIS 551 AEADSAAATAAAETMTQDKMN ILDAILESGINTIQESVYNLDSPLSWSGPLTPPTFLLS

537 TVTSISSCIEQLEKSWSQY LA . . . C PEDISGLLHS ITLLAHLT SDATAHGATTCLRA. PP 482 RAQEALDAVSTLEEGHAQYLT . . SLADASALVAALTRF SHLAADTIINGGATSHLA.PT 611 LLESTSENATEFATSFNNLIVDG LAHGDQTEVIHCVSDF ST SMATLVTNSKAYAVTTLPQ

593 EPADSLTEACKQYGRETLAYLASLE EEG SLENADSTAMRNCLSKTKA IGEE LLPRGLD IK 538 DPADRLIDTCRECGARALELMGQLQDQQALRHMQASLVRTPLOGILQLGQELKPKSLDVR 671 EQSDQILTLVKRCAREAQYFF ELMSENLNQVGDEEKTDIVINANVDMQEKLQELSLAIE

653 Q. .EELGDLVDK EMAAT SAA I ETATAR I EEMLSK SRAGDTGVKLEVNER I LG CCTSLMQA 598 Q. . EELGAVVDK EMAAT SAA I EDAVRR I EDMMNQARHASSG VK LEVNER I LN SC TDLMKA 731 PLLNIQSVKSNK ETNPHSELVATADKIVK........ SSEHLRVDVPKPLLSLALM IIDA

711 TQVLIVASK DLORE I VE SG RGMASS P KE F Y AKNSRWTEG L I S A S K AVGWGATVMVDAADLV 656 IRLLVTTST SLQKE IVE S R RAATQQEF Y AKN SRWT EG L I SASKAVGWGATQLVEAADKV 783 VVALVKAAIQCQNEI. . ATTTS I PLNQFYLKNSRWTEGL I SAAKAVAGATNVLITTASKI

771 VQGRGKF . . . . E E LMVC SHE I AA S TA Q LVAA SKVKADKDS PNLAQLQQASRGVNQA. . . . 716 VLHTGKY.... EEL IVCSHE IAASTAQLVAASKVKANKHS PHLSRLQECSRTVNER . . . 841 ITSEDNENTS PEQF IVASKEVAASTTQLVAA SRVKT S IHSKAQDKLEHC SKDDTDACRSL

823 TAGVVASTISGKSQ I EETDNMD F S SMTLTQ IKRQ E MDSQVRVLE LENELQKERQKLG E LR 768 AANVVASTKSGQEQI EDRDTMDF SGLSLIKLKKOEMETOVRVLELEKTLEAERMRLGELR 901 GNHVMGMIEDDHSTSQQQQP IDFTSEH. TLKTAEMEQQVETLKLEQSLSNARKRLG EIR

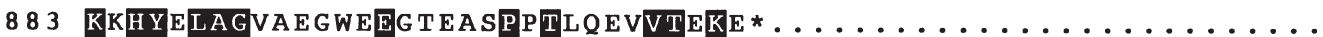
828 KQHYVLAGASG SPGEEVAIRPSTAPRSVTTKKP PLAQKP SVAPRQDHQLDKKDG IY PAQL

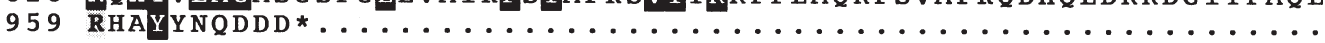

$888 \dot{\mathrm{V}} \dot{\mathrm{N}} \ddot{\mathrm{Y}}$

...

Fig. 1 Alignment of HIP1 (accession number U79734), HIP1R (accession number AB013384), and Sla2p (accession number Z22811). Identities are indicated by black background and similar residues are shaded. An asterisk denotes the termination codon 
polyadenylation signal, AATAAA, was located $23 \mathrm{bp}$ upstream of a poly A. Homology search of the conceptual translated amino acid sequence of the isolated cDNA revealed that it was most homologous to HIP1 (Kalchman et al. 1997), having $56 \%$ identity at the amino acid level, and thus we named the gene for the cDNA huntingtin interacting protein-related (HIP1R). The alignment of the predicted amino acid sequences of HIP1, HIP1R, and Sla2p is shown in Fig. 1. A homology search for HIP1 revealed that the HIP1 gene product shares significant similarity with the Sla2 gene product from $S$. cerevisiae, which is known to code for an essential cytoskeletal-associated protein (Kalchman et al. 1997; Wanker et al. 1997). Kalchman et al. (1997) suggested that an increased polyglutamine tract could disturb the normal interaction of huntingtin with HIP1 which, in turn, could lead to an alteration of biological events on the membrane causing premature cell death and ultimately the clinical manifestations of HD.

Since HIP1R has a high sequence homology to HIP1 in the amino terminal region, which was shown to be responsible for the interaction with huntingtin (Wanker et al. 1997), it is conceivable although not proven that HIP1R also interacts with huntingtin in its amino terminal region. Our sequence analysis revealed a highly conserved motif consistent with a leucine zipper encompassing the amino acid residues 329-357 (LEEKSDQLEKLKRELEAKAGELARAQEAL) of HIP1R. In HIP1 and Sla2p, a leucine zipper motif is found at the region of amino acid residues 412-433 (LESLKQELGTSQRELQVLQGSL) and 481502 (LAKLYSQLRQEHLNLLPRFKKL), respectively. Leucine zippers are known to mediate protein-protein interactions occurring in the cytoskeleton, or to act in transcriptional activations by allowing the formation of homo- or hetero-dimers of transcription-regulating proteins (John et al. 1994; Pearlman et al. 1994). The leucine zipper motifs conserved among the HIP1 family could contribute to some important role(s) in interaction with other proteins.

We examined the tissue distribution of HIP1R transcript in various tissues by reverse transcription-coupled polymerase chain reaction (RT-PCR). Primers used for RTPCR correspond to the coding region of the gene. Considering its ubiquitous expression in a wide variety of human tissues (Fig. 2), HIP1R described in the present study seems to be involved in a basic housekeeping function of cells.

We determined the chromosomal location of the HIP1R gene using a radiation hybrid panel (Genebridge 4, Research Genetics, Huntsville, AL, USA) in the same manner of previous reports (Saito et al. 1997; Seki et al. 1997). Primers used for PCR amplification correspond to the $3^{\prime}$ UTR region of the gene (5'-CCTGAAGGTCGTGGATGGATG- $\left.3^{\prime}\right)$ and (5'-CTGGTAGAATCGGTGCCCCAG-3') (102-bp PCR product). The radiation hybrid mapping data was processed using the RHMAPPER software package (http://www-genome.wi.mit.edu/cgi-bin/ contig/rhmapper.pl). The data vector for the HIP1R gene was $0010100001 \quad 1000100000 \quad 01001001010001010010$ 00001100001000000000000000101010011000000100011010

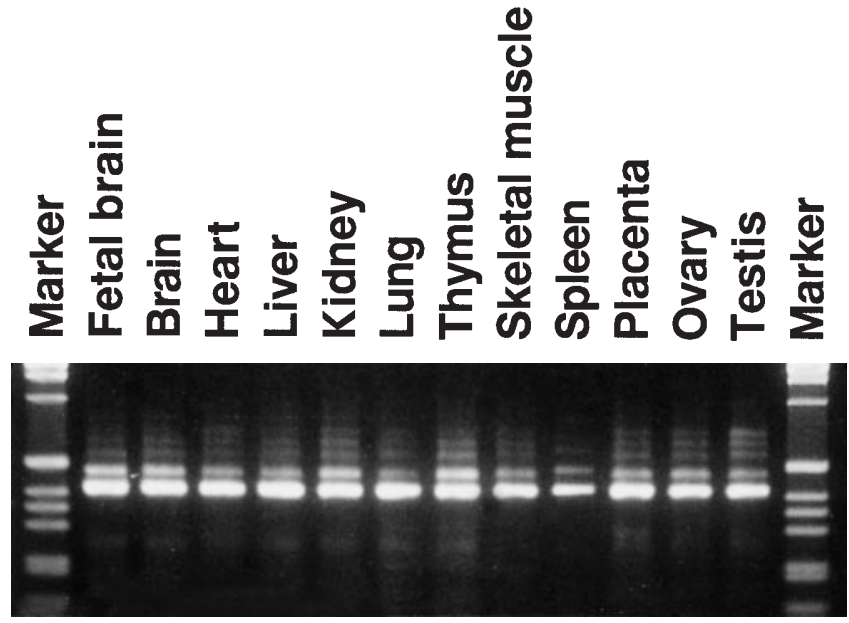

Fig. 2 Primers used for RT-PCR were to amplify the $425 \mathrm{bp}$ cDNA of the transcript. The primers were (5'-GAAATGCTCCGCTCTGAACTG-3') and (5'-AACTCCGACTCCCGCTTCACC- $\left.3^{\prime}\right)$. The primer set gave the longer PCR product from genomic DNA which was easily distinguished from the $425 \mathrm{bp}$ product from the mRNA. The templates of the human tissues of poly $(\mathrm{A})^{+}$RNAs were purchased from Clontech (Palo Alto, CA, USA). The cDNA templates for RT-PCR were synthesized from $2 \mu \mathrm{g}$ of poly $(\mathrm{A})^{+}$using excess amounts of Superscript II reverse transcriptase (Gibco BRL, Gaithersburg, MD, USA) and random hexamer primers. PCR was carried out in a final volume of $10 \mu \mathrm{l}$ containing $1 \times$ LA-PCR buffer (Takara, Kyoto, Japan), $2 \mu \mathrm{M}$ each primer, $200 \mu \mathrm{M}$ each dNTP, $1 \mu \mathrm{l}$ of template DNA and 0.01 units of LATaq DNA polymerase (Takara, Kyoto, Japan). Temperature and time schedule were 30 cycles of $95^{\circ} \mathrm{C}$ for $20 \mathrm{~s}$ and $62^{\circ} \mathrm{C}$ for $1 \mathrm{~min}$. PCR products were separated on $2.5 \%$ Nusieve GTG agarose gel (FMC, Rockland, ME, USA) with a $1 \mathrm{~kb}$ ladder DNA marker (Gibco)

110 and the consequent statistical report indicated the gene was mapped to $4.81 \mathrm{cR}$ distal from WI-6021 ( $\mathrm{lod}>3.0)$ which maps cytogenetically to the $12 \mathrm{q} 24$ region. To confirm the PCR-based chromosome mapping by an independent approach, we performed fluorescence in situ hybridization (FISH) using a P1 phage DNA probe as described previously (Seki et al. 1997). The P1 clone containing the HIP1R sequence was isolated by the method described previously (Ohira et al. 1997). The clear doublet signals were consistently demonstrated on the q24.2-q24.3 region of chromosome 12 (Fig. 3). Therefore, the gene was mapped on the q24.2-q24.3 region of chromosome 12. Some of the neurodegenerative disease was mapped to the vicinity of this region including scapuloperoneal syndromes (Isozumi et al. 1996), the distal hereditary motor neuropathy (distal HMN) or the spinal form of Charcot-Marie-Tooth (CMT) disease (Timmerman et al. 1996). Homology between HIP1R and HIP1 implies the possible involvement of HIP1R in these neurodegenerative diseases. Our precise chromosomal positioning data of the HIP1R gene might contribute to the ongoing positional candidate approaches for the disease genes which are linked to the genomic region. 
Fig. 3a-c Fluorescence in situ hybridization (FISH) of the HIP1R gene. FISH was carried out using a biotinylated hybridization probe made from P1 phage clone harboring the HIP1R gene. Arrows indicate the hybridization signals on human chromosome 12q24.2-q24.3. The metaphase spreads were photographed with a Nikon (Tokyo, Japan) B-2A filter
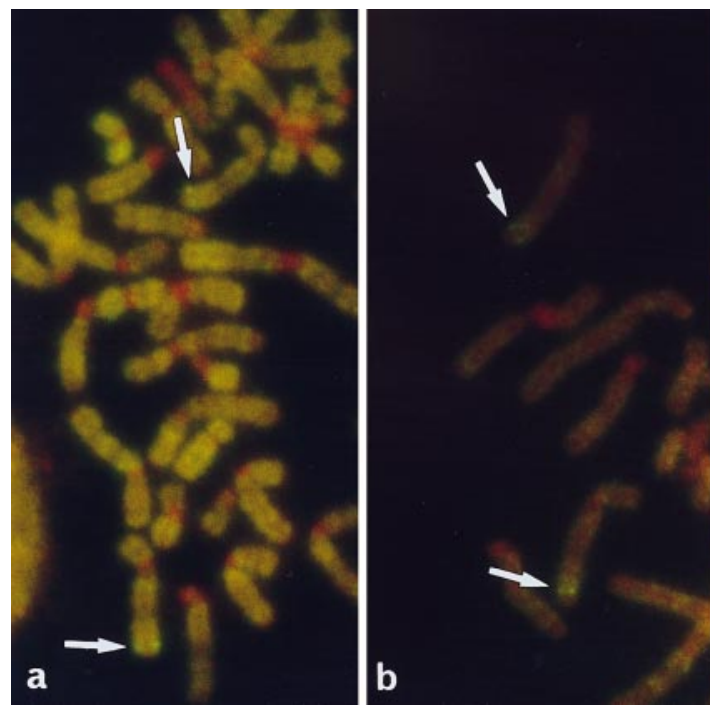

\section{References}

Andrew SE, Goldberg YP, Kremer B, Telenius H, Theilmann J, Adam S, Starr E, Squitieri F, Lin B, Kalchman MA, Graham RK, Hayden MR (1993) The relationship between trinucleotide (CAG) repeat length and clinical feature of Huntington's disease. Nat Genet 4 : 398-403

Burke JR, Enghild JJ, Martin ME, Jou YS, Myers RM, Roses AD, Vance JM, Strittmatter WJ (1996) Huntingtin and DRPLA proteins selectively interact with the enzyme GAPDH. Nat Med 2: 347350

Duyao M, Ambrose C, Myers R, Novelletto A, Persichetti F, Frontali M, Folstein S, Ross C, Franz M, Abbott M, Gray J, Conneally P, Young A, Penney J, Hollingsworth Z, Shoulson I, Lazzarini A, Falek A, Koroshetz W, Sax D, Bird E, Vonsattel J, Bonilla E, Alvir J, Conde JB, Cha JH, Dure L, Gomez F, Ramos M, Sanchez-Ramos J, Snodgrass S, de Young M, Wexler N, Moscowitz C, Penchaszadeh G, MacFarlane H, Anderson M, Jenkins B, Srinidhi J, Barnes G, Gusella J, MacDonald M (1993) Trinucleotide repeat length instability and age of onset in Huntington disease. Nat Genet 4: 387-392

Harper PS (1991) Huntington's disease. WB Saunders, London

Isozumi K, DeLong R, Kaplan J, Deng HX, Iqbal Z, Hung WY, Wilhelmsen KC, Hentati A, Pericak-Vance MA, Siddique T (1996) Linkage of scapuloperoneal spinal muscular atrophy to chromosome 12q24.1-q24.31. Hum Mol Genet 5: 1377-1382

John M, Briand JP, Granger-Schnarr M, Schnarr M (1994) Two pairs of oppositely charged amino acids from Jun and Fos confer heterodimerization to GCN4 leucine zipper. J Biol Chem 269: 16247-16253

Kalchman MA, Graham RK, Xia G, Koide HB, Hodgson JG, Graham KC, Goldberg YP, Gietz RD, Pickart CM, Hayden MR (1996) Huntingtin is ubiquitinated and interacts with a specific ubiquitinconjugating enzyme. J Biol Chem 271: 19385-19394

Kalchman MA, Koide HB, McCutcheon K, Graham RK, Nichol K, Nishiyama K, Kazemi-Esfarjani P, Lynn FC, Wellington C, Metzler M, Goldberg YP, Kanazawa I, Gietz RD, Hayden MR (1997) HIP1, a human homologue of $S$. cerevisiae Sla2p, interacts with membraneassociated huntingtin in the brain. Nat Genet 16: 44-53

Kremer B, Goldberg P, Andrew SE, Theilmann J, Telenius H, Zeisler J, Squitieri F, Lin B, Bassett A, Almqvist E, Bird TD, Hayden MR (1994) A worldwide study of the Huntington's disease mutation: the sensitivity and specificity of measuring CAG repeats. N Engl J Med 330: 1401-1406
Li XJ, Li SH, Sharp AH, Nucifora FC Jr, Schilling G, Lanahan A, Worley P, Snyder SH, Ross CA (1995) A huntingtin-associated protein enriched in brain with implications for pathology. Nature 378: 398-402

Maruyama K, Sugano S (1994) Oligo-capping: a simple method to replace the cap structure of eukaryotic mRNAs with oligoribonucleotides. Gene 138: 171-174

Ohhira M, Seki N, Nagase T, Suzuki E, Nomura N, Ohara O, Hattori M, Sakaki Y, Eki T, Murakami Y, Saito T, Ichikawa H, Ohki M (1997) Gene identification in 1.6-Mb region of the Down syndrome region on chromosome 21. Genome Res 7: 47-58

Pearlman JA, Powaser PA, Elledge SJ, Caskey CT (1994) Troponin T is capable of binding dystrophin via a leucine zipper. FEBS Lette 354: $183-186$

Ross CA (1995) When more is less: pathogenesis of glutamine repeat neurodegenerative disease. Neuron 15: 493-496

Saito T, Seki N, Ishii H, Ohhira M, Hayashi A, Kozuma S, Hori T (1997) Complementary DNA cloning and chromosomal mapping of a novel phosphatidylinositol kinase gene. DNA Res 4: 301-305

Seki N, Nimura Y, Ohhira M, Saito T, Ichimiya S, Nomura N, Nakagawara A (1997) Identification and chromosome assignment of a human gene encoding a novel phosphatidylinositol-3 kinase. DNA Res 4: 355-358

Snell RG, MacMillan JC, Cheadle JP, Fenton I, Lazarou LP, Davies P, MacDonald ME, Gusella JF, Harper PS, Shaw DJ (1993) Relationship between trinucleotide repeat expansion and phenotypic variation in Huntington's disease. Nat Genet 4: 393397

Suzuki Y, Yoshitomo-Nakagawa K, Maruyama K, Suyama A, Sugano S (1997) Construction and characterization of a full length-enriched and 5'-end-enriched cDNA library. Gene 200: 149-156

The Huntington's Disease Collaborative Research Group (1993) A novel gene containing a trinucleotide repeat that is expanded and unstable on Huntington's disease chromosomes. Cell 72: 971983

Timmerman V, De Jonghe P, Simokovic S, Lofgren A, Beuten J, Nelis E, Ceuterick C, Martin JJ, Van Broeckhoven C (1996) Distal hereditary motor neuropathy type II (distal HMN II): mapping of a locus to chromosome 12q24. Hum Mol Genet 5: 1065-1069

Wanker EE, Rovira C, Scherzinger E, Hasenbank R, Walter S, Tait D, Colicelli J, Lehrach H (1997) HIP-I: a huntingtin interacting protein isolated by the yeast two-hybrid system. Hum Mol Genet 6: 487495

Zoghbi HY (1996) The expanding world of ataxins. Nat Genet 14: 237238 